J. Clin. Chem. Clin. Biochem.

Vol. 21,1983 , pp. $145-150$

\title{
Determination of HDL Phosphatidyl Choline by an Enzymatic Method
}

\author{
By H. Schriewer, H. U.Jabs, V. Günnewig and G. Assmann

\begin{abstract}
Zentrallaboratorium der Medizinischen Einrichtungen der Westfälischen Wïhelms-Universität Münster/Westfalen
\end{abstract}

(Received March 8/September 14, 1982)

\begin{abstract}
Summary: A routine method is described for the enzymatic determination of phosphatidyl choline in the apolipoprotein B-free supernatant after precipitation of blood sera with phosphotungstic acid/ $\mathrm{MgCl}_{2}$. The principle of this method is based on the specific cleavage of phosphatidyl choline by purified phospholipase $C$ from $B$. cereus, and the enzymatic determination of choline by choline kinase after hydrolysis of phosphorylcholine. The enzymatic method provides HDL phosphatidyl choline values which coincide with those of the conventional chemical method. Furthermore, the values obtained with the enzymatic method for the HDL fraction isolated by ultracentrifugation $(1.063-1.21 \mathrm{~kg} / \mathrm{l})$ also closely coincide with those of the apolipoprotein B-free supernatant fraction. The precision, linearity and sample stability were also checked. The findings obtained show that the enzymatic assay introduced here is suitable for the routine determination of phosphatidyl choline in the apolipoprotein B-free supernatant.
\end{abstract}

HDL phosphatidyl choline values of $1.18 \pm 0.37 \mathrm{mmol} / \mathrm{l}(162 \mathrm{men})$ and $1.37 \pm 0.38 \mathrm{mmol} / \mathrm{l}$ (59 women) were obtained using this method in normal individuals.

\section{Zur Analytik von HDL Phosphatidylcholin mit einer enzymatischen Bestimmungsmethode}

Zusammenfassung: Es wird eine Routinemethode für die enzymatische Bestimmung von Phosphatidylcholin im Apoliprotein B-freien Uberstand nach Fälluñg von Blutseren mit Phosphorwolframsäure $/ \mathrm{MgCl}_{2}$ beschrieben. Das Prinzip dieser Methode besteht in der spezifischen Spaltung von Phosphatidylcholin mit gereinigter Phospholipase $\mathbf{C}$ aus $\boldsymbol{B}$. cereus und der anschließenden enzymatischen Bestimmung von Cholin mittels Cholinkinase nach Hydrolyse von Phosphorylcholin. Im Vergleich zur konventionellen chemischen Methode ergab die enzymatische Methode übereinstimmende HDL Phosphatidylcholinwerte. Weiterhin wurden übereinstimmende Ergebnisse mit der enzymatischen Methode zwischen der HDL-Fraktion, die durch Ultrazentrifugation $(1,063-1,21 \mathrm{~kg} / \mathrm{l})$ isoliert wurde, und der Apolipoprotein B-freien Úberstandsfraktion erzielt. Die Präzision, Linearität und Probenstabilität wurden ebenfalls untersucht. Die Ergebnisse zeigen, daß die eingeführte enzymatische Methode für die routinemäßige Bestimmung von Phosphatidylcholin im Apolipoprotein B-freien Überstand geeignet isț. Mit dieser Methode fanden wir in der Normalbevölkerung für Männer $(n=162)$ einen HDL Phosphatidylcholinwert von $1,18 \pm 0,37 \mathrm{mmol} / \mathrm{l}$ und bei Frauen $(n=59)$ einen HDL Phosphatidylcholinwert von $1,37 \pm 0,38 \mathrm{mmol} / \mathrm{h}$.

\section{Introduction}

In recent years the quantitation of high density lipoproteins (HDL) as an indicator of the risk of coronary heart disease has gained particular importance $(1,2)$. The typical routine methods for determining HDL involve quantitative analysis of the cholesterol constituent of HDL. However, the HDL do not represent a single substance, but are a heterogeneous mixture of macromolecules, whose composition depends to a considerable degree on the metabolism of HDL. For instance, in hypertriglyceridaemic sera the cholesterol constituent of HDL decreases with a con- 
comitant increase in the triglyceride values of these particles $(3,4)$. Thus the HDL cholesterol value is not representative for the HDL mass, but only reflects the cholesterol constituent of this particle fraction. In order to be able to gain information about the HDL mass or the HDL composition, it is necessary to determine simultaneously additional HDL components such as HDL apolipoproteins and HDL phospholipids. Whereas additional determination of HDL apolipoproteins has recently gained increasing importance in clinical $(4,5,6)$ and epidemiological studies (7), the analysis of HDL phospholipids or HDL phospholipid fractions such as HDL phosphatidyl choline and HDL sphingomyelin have not so far been incorporated into routine analysis, due to the elaborate nature of the analysis involved.

Recently an enzymatic method for determining phosphatidyl choline in amniotic fluid was developed (8). This assay involves phospholipase C-catalysed cleavage of phosphatidyl choline to yield diglycerides and phosphorylcholine, as well as hydrolytic cleavage of phosphorylcholine by alkaline phosphatase and spectral photometric analysis of choline using choline kinase. We have tested this method of measuring phosphatidyl choline in the supernatant fraction following precipitation of apolipoprotein B-containing lipoproteins with phosphotungstic acid/ $\mathrm{MgCl}_{2}$ (HDL phosphatidyl choline).

\section{Materials and Methods}

Phosphotungstic acid/ $\mathrm{MgCl}_{2}$ precipitation reagent Boehringer Mannheim, Test-No.: 400971

Phospholipase $C$ from $B$. cereus (EC 3.1.4.3), maximum purity Boehringer Mannheim, Order-No.: 241709

(Phospholipase $\mathrm{C}$ was diluted to $80 \mathrm{U} / \mathrm{ml}$ with $3.2 \mathrm{~mol} / \mathrm{l}$ ammonium sulphate)

Alkaline phosphatase (EC 3.1.3.1), specific activity $65 \mathrm{U} / \mathrm{mg}$ Boehringer Mannheim, Order-No.: 108162

Choline kinase from yeast (EC 2.7.1.32), specific activity 0.5 $\mathrm{U} / \mathrm{mg}$

Boehringer Mannheim, Order-No.: 348651

Lactate dehydrogenase, (EC 1.1.1.27), specific activity $550 \mathrm{U} / \mathrm{mg}$ at $25^{\circ} \mathrm{C}$ from rabbit muscle

Boehringer Mannheim, Order-No.: 127330

Pyruvate kinase (EC 2.7.1.40), specific activity $200 \mathrm{U} / \mathrm{mg}$ at $25^{\circ} \mathrm{C}$ from rabbit muscle

Boehringer Mannheim, Order-No.: 127418

Sample material

Sera from the experimental series "Prospective epidemiological study in company employees in Westfalia" were used as sample material. Blood samples were drawn in the morning in a specially equipped bus after a fasting period of at least 12 hours. The serum samples obtained were stored at $+4^{\circ} \mathrm{C}$ and arrived at our laboratory after a maximum of 3 days. Analysis was carried out within 24 hours after receiving the serum samples.
Methods

\section{$H D L$ isolation}

$\mathrm{HDL}$ was isolated by ultracentrifugation or precipitation of apolipoprotein B-containing lipoproteins as described previously in detail (9).

\section{Enzymatic determination of phosphatidyl chóline}

Phosphatidyl choline was determined enzymatically according to the following principle:

\section{Reactions}

\begin{tabular}{|c|c|c|}
\hline Phosphatidyl choliñe & phospholipase C & $\begin{array}{l}\text { phosphorylcholine } \\
\text { + diglycerides }\end{array}$ \\
\hline Phosphorylcholine & $\stackrel{\text { alkaline.phosphatase }}{\longrightarrow}$ & choline + phosphate \\
\hline Choline + ATP & choline kinase & $\begin{array}{l}\text { phosphorylcholine } \\
\text { + ADP }\end{array}$ \\
\hline $\begin{array}{l}\text { ADP + phosphoen } \\
\text { pyruvate }\end{array}$ & pyruvate kinase & ATP + pyruvate \\
\hline $\begin{array}{l}\text { Pyruvate } \\
+\mathrm{NADH}+\mathrm{H}^{+}\end{array}$ & lactate dehydrogenase & lactate $+\mathrm{NAD}^{+}$ \\
\hline
\end{tabular}

The following reagents were pipetted into Eppendorf reaction tubes:

\begin{tabular}{|c|c|c|c|c|}
\hline tubes: & $\begin{array}{l}\text { Sample } \\
\text { (ml) }\end{array}$ & & $\begin{array}{l}\text { Reàger } \\
(\mathrm{ml})\end{array}$ & blank \\
\hline $0.15 \mathrm{~mol} / \mathrm{l} \mathrm{NaCl}$ & 0.980 & & 1.000 & \\
\hline $\begin{array}{l}\text { Glycine buffer }(0.2 \mathrm{~mol} / \mathrm{l} \\
\text { glycine, } 10 \mathrm{mmol} / 1 \mathrm{MgSO}_{4} \\
\times 7 \mathrm{H}_{2} \mathrm{O}, 0.1 \mathrm{~g} / \mathrm{l} \text { sodium } \\
\text { dodecylsulph }\end{array}$ & 0.500 & & 0.500 & . \\
\hline Phospholipase C & 0.050 & $(4 \mathrm{U})$ & 0.050 & $(4 U)$ \\
\hline Alkaline phosphatase & 0.010 & $(6,5 U)$ & 0.010 & $(6,5 \mathrm{U})$ \\
\hline Sample & 0.020 & & --- & \\
\hline
\end{tabular}

The mixture is incubated for 30 minutes at $37^{\circ} \mathrm{C}$ followed by denaturation of proteins by heating at $95^{\circ} \mathrm{C}$ for 10 minutes. After cooling to room temperature, the denatured proteins are centrifuged out in an Eppendorf 3200 centrifuge. From the supernatant obtained from the sample solution and reagent blank solution $1 \mathrm{ml}$ is placed in Eppendorf $\mathrm{K}$ cuvettes (No. 4071 306.009), to which are added $0.050 \mathrm{ml}$ coenzyme solution $\left.{ }^{1}\right)(4 \mathrm{mmol} / 1 \mathrm{NADH}$, $20 \mathrm{mmol} / / \mathrm{ATP}, 7 \mathrm{mmol} / \mathrm{h}$ phosphoenolpyruvate (crystallized tricyclohexylammonium salt), and $0.020 \mathrm{ml}$ pyruvate kinase/lactate dehydrogenase mixture ( $300 \mathrm{kU} / \mathrm{l}$ each). The reaction solution is then mixed well and, after 10 minutes of incubation at $37^{\circ} \mathrm{C}$, the absorbance $A_{1}$ is measured at $365 \mathrm{~nm}$ (against $\mathrm{H}_{2} \mathrm{O}$ ). Afterwards $0.025 \mathrm{ml}$ choline kinase $(2 \mathrm{kU} / \mathrm{l})$ is pipetted into the solution and mixed well; absorbance $A_{2}$ is then measured after 7 minutes, and absorbance $A_{3}$ after an additional 7 minutes.

calculations:

$\Delta A$ (sample, blank $)=\left(A_{1}-A_{2}\right)-\left(A_{2}-A_{3}\right)$

$\Delta \mathrm{A}=\Delta \mathrm{A}_{\text {sample }}-\Delta \mathrm{A}_{\text {blank }}$

Concentration $=\frac{\Delta \mathrm{A} \times 1.56 \times 1.095 \times 1.1}{0.02 \times 1 \times 3.44}[\mathrm{mmol} / \mathrm{l}]$

The factor of 1.1 is omitted in the determination of HDL phosphatidyl choline in samples isolated by ultracentrifugation.

1) the solution also contains $45 \mathrm{mmol} / 1$ glucise (9) 
Determination of phosphatidyl choline after separation of phospholipids by thin layer chromatography

The phospholipids are extracted, the thin layer chromatography of phospholipids is carried out and the phosphate is assayed as described in detail elsewhere (9).

\section{Results}

Accuracy and precision of the HDL phosphatidyl choline assay

Regression analysis of the data collected after precipitation with phosphotungstic acid/ $\mathrm{MgCl}_{2}(\mathrm{y})$ and following ultracentrifucation $(x)$ showed close agreement of the HDL phosphatidyl choline values from both isolation methods $(r=0.93 ; y=0.93 x+0.11)$ (fig. 1).

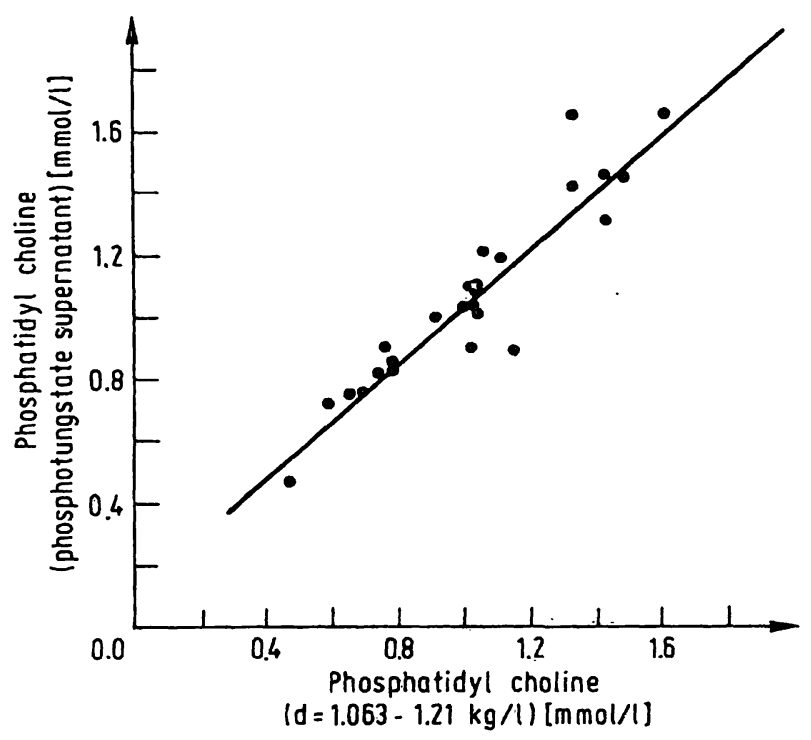

Fig. 1. Regression analysis of the phosphatidyl choline values, as determined from the HDL fractions isolated by ultracentrifugation $(1.063-1.21 \mathrm{~kg} / \mathrm{l})(\mathrm{x})$ and from the supernatant fraction isolated by precipitating apolipoprotein Bcontaining lipoproteins $(y)$.

$y=0.93 x+0.11 ; r=0.93$

Moreover, comparison of the HDL phosphatidyl choline values obtained by the enzymatic method $(y)$ with those obtained by the conventional chemical method $(x)$ (separation of phosphatidyl choline by thin layer chromatography following lipid extraction, phosphate determination after hydrolysis with perchloric acid) showed a good measure of agreement $(r=0.85 ; y=0.81 x+0.28$ ) (fig. 2). Comparison with the conventional standard method could only be performed with HDL fractions which has been isolated by sequential ultracentrifugation, since the phosphatidyl choline fractions isolated from the apolipoprotein B-free supernatant were contaminated with phosphotungstic acid.

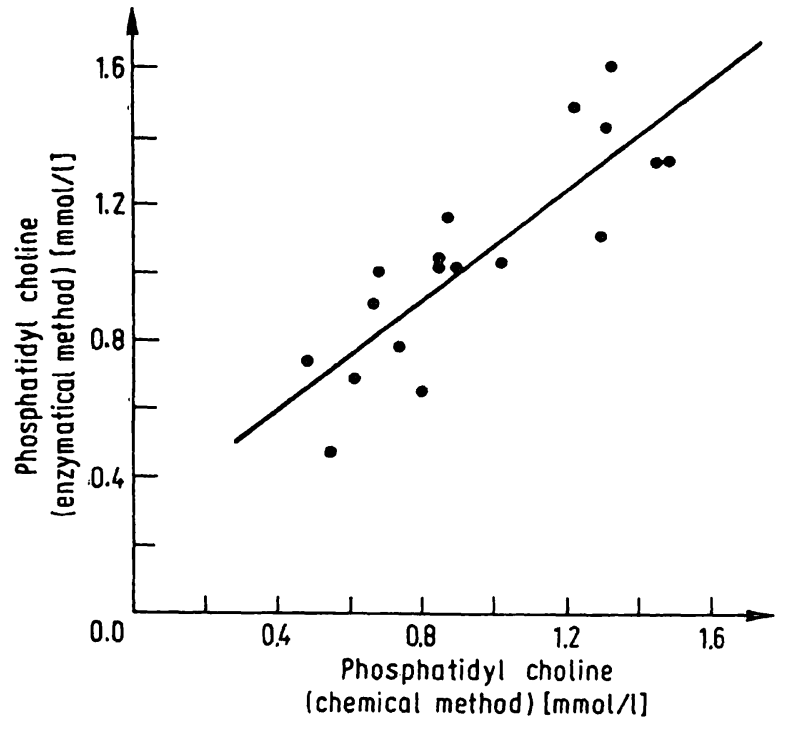

Fig. 2 Regression analysis of the HDL phosphatidyl choline values $(1.063-1.21 \mathrm{~kg} / 1)$ analysed by both the chemical method $(x)$ and the enzymatic method $(y)$.

$y=0.81 x+0.82 ; r=0.28$

A value of $6.5 \%(\bar{x} \pm S D: 1.60 \pm 0.11 \mathrm{mmol} / /$; $\mathrm{n}=20$ ) was determined as the variation coefficient for the precision in series. The variation coefficient for the precision from day to day, as determined from serum samples stored at $-18^{\circ} \mathrm{C}$, was $10.5 \%$ ( $\overline{\mathrm{x}} \pm \mathrm{SD}: 0.90 \pm 0.09 \mathrm{mmol} / \mathrm{l} ; \mathrm{n}=14)$.

\section{Specificity of the HDL phosphatidyl choline assay}

By thin layer chromatography of the lipid extract, which was isolated from the apolipoprotein B-free supernatant after the action of phospholipase C (0.5 - $4 \mathrm{U}$ phospholipase $C$ per $100 \mu l$ solution), we only observed cleavage of phosphatidyl choline and not of sphingomyelin or of lysosphatidyl choline (not shown).

\section{Linearity of the HDL phosphatidyl choline assay}

The linearity of the enzymatic determination of HDL phosphatidyl choline was checked by addition of various sample volumes to the test solution. As illustrated in figure 3 , the differences in absorbance measured in the range between $0.010 \mathrm{ml}$ and $0.150 \mathrm{ml}$ of sample (apolipoprotein B-free supernatant) pèr incubation solution were directly proportional to the added sample volumes.

\section{Sample stability}

Storage of the sample materials may have an effect on the accuracy of the HDL phosphatidyl choline values due to the activity of lecithin: cholesterol 


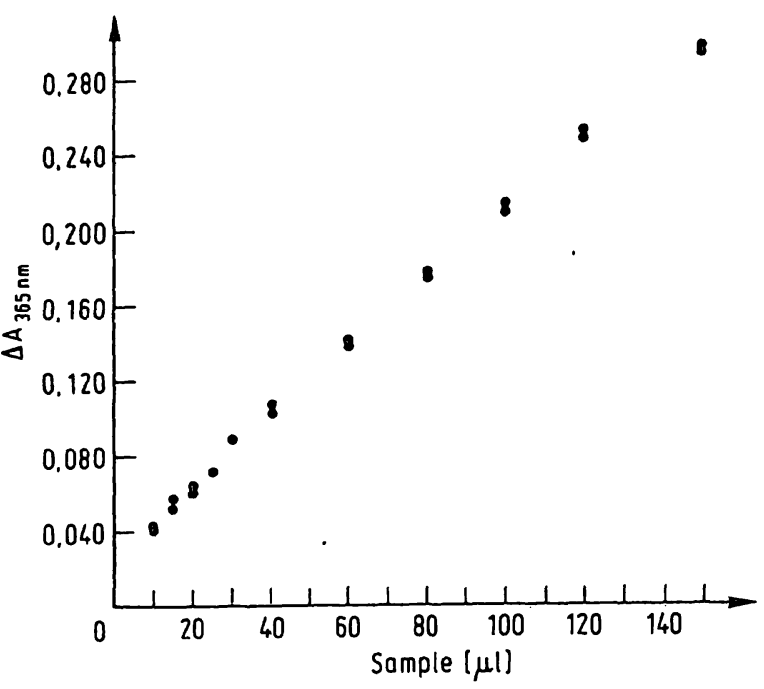

Fig. 3. Measured values as a function of the sample volume used in the enzymatic determination of HDL phosphatidyl choline; double values were collected for the assay.

acyltransferase (LCAT) or phospholipases in the serum. In order to investigate the possible influence of the time interval between drawing blood and centrifuging the sample, 4 different blood samples were centrifuged at various times after the blood was drawn. As indicated in table 1 there was no difference in HDL phosphatidyl choline values for the samples left standing at room temperature for between 15 and 120 minutes after the blood was drawn. Furthermore, neither storage of blood sera for 1 week at $-18^{\circ} \mathrm{C}$, nor storage of blood sera or the corresponding apolipoprotein B-free supernatants for 72 hours at $+4{ }^{\circ} \mathrm{C}$ had any effect on the HDL phosphatidyl choline concentrations (table 2). However, storage of sera or the corresponding apolipoprotein B-free supernatants at $+20^{\circ} \mathrm{C}$ for 24 hours resulted in a slight decrease (on the average $6 \%$ and $10 \%$, respectively) in the HDL phosphatidyl choline values. A decrease (average 16\%) of the original HDL phosphatidyl choline values was observed only after the blood sera had been stored for 1 week at $+4{ }^{\circ} \mathrm{C}$.

Tab. 1. HDL phosphatidyl choline values from the apolipoprotein B-free supernatant of blood sera as a function of the time between drawing the blood and centrifugation of the sample, in 4 different probands.

HDL phosphatidyl choline $(\mathrm{mmol} / \mathrm{l})$

\begin{tabular}{rllll}
\hline $\begin{array}{l}\text { Time } \\
\text { [min] }\end{array}$ & $\begin{array}{l}\text { Proband } \\
\text { 1 }\end{array}$ & $\begin{array}{l}\text { Proband } \\
2\end{array}$ & $\begin{array}{l}\text { Proband } \\
3\end{array}$ & $\begin{array}{l}\text { Proband } \\
4\end{array}$ \\
\hline 15 & 1.26 & 1.65 & 1.14 & 1.50 \\
45 & 1.25 & 1.68 & 1.10 & 1.50 \\
90 & 1.26 & 1.68 & 1.06 & 1.50 \\
120 & 1.39 & 1.69 & 1.10 & 1.54 \\
\hline
\end{tabular}

Tab. 2. Percentage change in HDL phosphatidyl choline values after storage of blood sera and apolipoprotein B-free supernatants; mean values \pm standard deviation from 10 different experiments.

\begin{tabular}{llll}
\hline $\begin{array}{l}\text { Storage } \\
\text { temperature } \\
{\left[{ }^{\circ} \mathrm{C}\right]}\end{array}$ & $\begin{array}{l}\text { Storage } \\
\text { period } \\
{[\mathrm{h}]}\end{array}$ & $\begin{array}{l}\text { Change } \\
\text { (sera) } \\
{[\%]}\end{array}$ & $\begin{array}{l}\text { Change } \\
\text { (supernatant) } \\
{[\%]}\end{array}$ \\
\hline+20 & 24 & $\left.-6.4 \pm 10.3^{1}\right)$ & $\left.-10.0 \pm 9.0^{3}\right)$ \\
+4 & 24 & $+0.6 \pm 9.6$ & $+0.9 \pm 6.2$ \\
+4 & 72 & $-3.5 \pm 14.7$ & $+1.8 \pm 9.9$ \\
+4 & 168 & $\left.-16.0 \pm 19.6^{2}\right)$ & \\
-18 & 168 & $+2.9 \pm 9.5$ & \\
\hline
\end{tabular}

significance: 1) $\mathrm{p}<0.1 \quad$ 2) $\mathrm{p}<0.05 \quad$ 3) $\mathrm{p}<0.01$

$H D L$ phosphatidyl choline values in normal individuals

Table 3 shows the HDL phosphatidyl choline values measured in normal individuals (162 men and 59 women). The HDL phospholipid fraction investigated exhibited nearly normal distribution in both sexes. In women, higher HDL phosphatidyl choline values were observed than in men $(p<0.01)$. As shown in table 4 , in both sexes HDL phosphatidyl choline values were independent of age.

Tab. 3. Distribution of HDL phosphatidyl choline values ( $\mathrm{mmol} / \mathrm{l}$ ) in normal individuals (prospective epidemiological study in company employees in Westfalia)

\begin{tabular}{|c|c|c|c|}
\hline & $\begin{array}{l}\text { Phosphat } \\
\text { men } \\
n=162 \\
{[\mathrm{mmol} / \mathrm{l}]}\end{array}$ & choline & $\begin{array}{l}\text { women } \\
\mathrm{n}=59 \\
{[\mathrm{mmol} / \mathrm{l}]}\end{array}$ \\
\hline Mean & 1.18 & & 1.37 \\
\hline Standard deviation & 0.37 & $\therefore \quad:$ & 0.38 \\
\hline Median & 1.14 & & 1.31 \\
\hline Minimum. & 0.24 & & 0.38 \\
\hline Maximum & 2.25 & & 2.42 \\
\hline $5 \%$ percentile & 0.60 & & 0.86 \\
\hline $25 \%$ percentile & 0.93 & & 1.14 \\
\hline $75 \%$ percentile & 1.39 & & 1.54 \\
\hline $95 \%$ percentile & 1.83 & & 2.01 \\
\hline
\end{tabular}

Tab. 4. HDL phosphatidyl choline values (mmol/ $/$ in normal individuals of different ages (Prospective epidemiological study in company employees in Westfalia)

\begin{tabular}{lll}
\hline $\begin{array}{l}\text { Age } \\
\text { [years] }\end{array}$ & $\begin{array}{l}\text { Phosphatidyl choline } \\
\text { Men } \\
{[\mathrm{mmol} / \mathrm{l}]}\end{array}$ & $\begin{array}{l}\text { Women } \\
{[\mathrm{mmol} / \mathrm{l}]}\end{array}$ \\
\hline $15-24$ & $\begin{array}{l}1.30 \pm 0.35 \\
(\mathrm{n}=17)\end{array}$ & $\begin{array}{l}1.32 \pm 0.30 \\
(\mathrm{n}=13)\end{array}$ \\
& $\begin{array}{l}1.21 \pm 0.35 \\
(\mathrm{n}=48)\end{array}$ & $\begin{array}{l}1.50 \pm 0.43 \\
(\mathrm{n}=16)\end{array}$ \\
$25-34$ & $\begin{array}{l}1.10 \pm 0.38 \\
(\mathrm{n}=54)\end{array}$ & $\begin{array}{l}1.38 \pm 0.47 \\
(\mathrm{n}=15)\end{array}$ \\
$35-44$ & $1.22 \pm 0.36$ & $\begin{array}{l}1.21 \pm 0.21 \\
(\mathrm{n}=8)\end{array}$ \\
$45-55$ & $\begin{array}{l}(\mathrm{n}=31) \\
1.17 \pm 0.43 \\
(\mathrm{n}=12)\end{array}$ & $\begin{array}{l}1.30 \pm 0.25 \\
(\mathrm{n}=7)\end{array}$ \\
\hline $55-64$ & &.$i$ \\
\hline
\end{tabular}




\section{Discussion}

The method used here to determine phosphatidyl choline in the apolipoprotein B-free supernatant of blood sera was developed for the analysis of phosphatidyl choline in amniotic fluid (8). The analytical principle is based on the enzymatic cleavage of phosphatidyl choline with phosphilipase $C$ and the enzymatic determination of the choline released after hydrolysis of the phosphorylcholine. The phospholipase $C$ from $B$. cereus. used in the test system specifically cleaves phosphatidyl choline' and does not cleave other choline containing phospholipids such as sphingomyelin and lysophosphatidyl choline.

Recently an enzymatic method for determination of total choline containing phospholipids (phosphatidyl choline, lysophosphatidyl choline, sphingomyelin) in the apolipoprotein B-free supernatant fraction has been reported using phospholipase $D$ and choline oxidase (10). However, the analysis of total choline containing phospholipids in the supernatant obtained after precipitation of apolipoprotein B-containing lipoproteins does not take account of the fact that a main part of the lysophosphatidyl choline moiety recovered in the supernatant is bound to albumin. The determination of the individual phospholipids e.g. phosphatidyl choline (or sphingomyelin), in the apolipoprotein B-free supernatant avoids this problem.

The determination of HDL phosphatidyl choline has not become routine, due to the elaborate nature of the analysis. To our knowledge, no HDL phosphatidyl choline data were hitherto available.

As our results show, the HDL phosphatidyl choline values obtained with the enzymatic method agree closely with the values obtained by the conventional standard method. Furthermore, we observed agreement of the phosphatidyl choline values from the apolipoprotein B-free supernatant fraction with those of the HDL fraction isolated by ultracentrifugation. The lines of regression analysis shown in figures 2 and 3 indeed do not cross the zero point. This may be due to statistical reasons since the intercepts are relatively low.

One of the most important problems with regard to the accuracy of the HDL phosphatidyl choline analysis in stored sample materials may be the potential effect of phosphatidyl choline cleaving enzymes. Among the enzymes involved, lecithin: cholesterol acyltransferase (LCAT) exerts the most influence on the stability of HDL phosphatidyl choline. However, as shown in the present work, the usual conditions of sample storage do not significantly affect HDL phos- phatidyl choline concentrations. As recently demonstrated by Albers et al. (11), the initial lecithin: cholesterol acyltransferase activity in plasma, measured as the initial rate of cholesterol esterification, was $0.106 \pm 0.03 \mathrm{mmol} / 1 \cdot \mathrm{h}$ at $37^{\circ} \mathrm{C}$. From this result it can be calculated that on average $10 \%$ of HDL phosphatidyl choline measured in normal individuals can be converted into lysophosphatidyl choline if the plasma is stored at $37^{\circ} \mathrm{C}$ for 1 hour. This calculation is also confirmed by recent results of Dieplinger \& Kostner (12). However, in our study, blood samples were usually stored at room temperature for 15 to 30 minutes before they were centrifuged, and the sera were stored at $+4^{\circ} \mathrm{C}$. Thus, it is unlikely that lecithin: cholesterol acyltransferase activity has a significant effect on the accuracy of our results. Our findings show that the influence of lecithin: cholesterol acyltransferase and phospholipases is even negligible if blood is centrifuged within 120 minutes after drawing, and also if the blood serum is stored for 2-3 days at $+4^{\circ} \mathrm{C}$, or one week at $-18^{\circ} \mathrm{C}$.

Recently we reported a method for the enzymatic determination of HDL sphingomyelin (9). The variation coefficients of $10.5 \%$ (precision from day to day) and $6.5 \%$ (precision in series) which we determined for the HDL phosphatidyl choline assay, are, however, slightly higher than the corresponding values we obtained in testing the precision of the HDL sphingomyelin assay (9). The lower precision for the HDL phosphatidyl choline assay as compared with the HDL sphingomyelin assay is apparently due to the greater dilution of samples for the HDL phosphatidyl choline assay. The dilution of $1: 50$ for the samples for the phospholipase C-catalyzed cleavage of phosphatidyl choline is necessary to avoid turbidity.

In view of increased interest in the determination of HDL phosphatidyl choline clinical laboratories need suitable material for quality control. Obviously lyophilized sera are not suitable for the precipitation of apolipoprotein B-containing lipoproteins $(2,12)$. The use of sera pools stored at $<-15^{\circ} \mathrm{C}$ may be an alternative. In our experience, in frozen sera, HDL phosphatidyl choline as well as other HDL constituents such as HDL apolipoprotein A-I, HDL apolipoprotein A-II or HDL sphingomyelin, are stable for more than 12 weeks.

The enzymatic method reported here is specific for phosphatidyl choline and involves considerably less effort than the conventional methods for determining phosphatidyl choline used to date. Assuming a sample load of 20-30 samples per day (duplicate assays), it is clear that this method is quite suitable for epidemiological studies. 


\section{References}

1. Assmann, G., Schriewer, H (1981) J. Clin. Chem. Clin. Biochem. 19,1-6.

2. Assmann, G., Schriewer, H. \& Funke, H. (1981) J: Clin. Chem. Clin. Biochem. 19, 273-278.

3. Strisower, E. H., Nichols, A. V., Lindgren, F. T. \& Smith, L (1965) J. Lab. Clin. Med. 65, 748-755.

4. Herbert, P. N. \& Henderson, L. O. (1979) Lancet $1,1368-$ 1370.

5. Kladetzky, R. G., Assmann, G., Walgenbach, S., Tauchert, P. \& Helb, H.-D. (1980) Artery 7, 191-205.

6. Ishikawa, T., Fidge, N., Thelle, D. S., Forde, O. H. \& Miller, N. E. (1978) Eur. J. Clin. Invest. 8, 179-182.

7. Assmann, G., Funke, H., Schriewer, H. (1982) J. Clin. Chem. Clin. Biochem., 20, 287-289.

8. Diedrich, K., Hepp, S., Welker, H., Krebs, D., Beuttler, H. O. \& Michal, G. (1979) Gëburtsh., Frauenheilk. 39, 849856.

9. Schriewer, H., Jabs, H. U. \& Assmann, G. (1982) J. Clin. Chemin. Clin. Bioçhem., 20, 305-312.

10. McGowan, M. W., Artiss, J. D. \& Zak, B. (1982) J. Clin. Chem. Clin. Biochiem. 20, 807-812.

11. Albers, J. J., Chen, C.-H. \& Adolphsoñ, J. L. (1981) J. Lipid Res. 22, 1206-1213.

12. Dieplinger, H. \& Kostner, G. M. (1980) Clin. Chim. Açta 106, 319-324.

13. Warnick, G. R., Mayfield, C. \& Albers, J. J. (1981) Clin. Chem. 27, 116-132.

Professor Dr. H. Schriewer

Zentrallaboratorien der Medizinischen Einrichtungen

der Westfälischen Wilhelms-Universität Domagkstraße 3

D-4400 Münster/Westf. 